\title{
Exploding and Being Swallowed: Cannibalism in Toni Morrison's Beloved
}

\author{
Lay Sion $\mathrm{Ng}$ \\ Graduate School of Language and Culture, Osaka University, Japan \\ Ruzbeh Babaee \\ Faculty of Modern Languages and Communication, University Putra Malaysia, Malaysia
}

Received: 07-11-2016

doi:10.7575/aiac.ijclts.v.5n.1p.11
Accepted: $19-12-2016$

Published: $31-01-2017$

\begin{abstract}
Cannibalism is a meta-discourse in Toni Morrison's Beloved. In Alan Rice's "Who's Eating Whom," Beloved's dream of "exploding and being swallowed" has been critically linked to the cruel practices of slavery, yet it is important to note the way in which the dream of "being swallowed" is largely unexplored. This paper concentrates on the latter aspect, stating that in Beloved, cannibalism and slavery relate not only to the domination of black slaves by white masters, but also to the black mother-child relationships between Sethe and Beloved, Sethe and Denver, and the black sister-sister relationship between Denver and Beloved. This paper argues that the whites designate themselves as the ones who represent civilization through implanting the image of cannibalism into the black Other. Ironically, the system of slavery precisely deconstructs the images that they have built of themselves, making them something no more than cannibals.
\end{abstract}

Keywords: Mother-daughter Relationship, Slavery, Black Identity, Deconstruction of White Cannibalism

\section{Introduction}

According to Rice, "Cannibalism is a central motif running through Toni Morrison's historical novel about slavery and its aftermath, Beloved" (Rice 107). In Beloved (1987), Beloved's "exploding and being swallowed" dream expresses the dismemberment of Beloved's body parts, which are then swallowed (157). Critiques have focused on Beloved's "exploding" dream, linking her "explosion" to the "oppressive practices in slavery" and claiming that throughout the text Morrison attempts to emphasize "the need to remember to heal the legacy of slavery" (Rice 108). However, the dream of "being swallowed" is largely unexplored, and is the main focus of the present study. This paper attempts to explore the relationship between cannibalism and slavery, which, in the novel, relates to the domination of black slaves by white masters, to black identity, and to the mother-child aspect regarding Sethe, Beloved and Denver. Before going through each section, it is worth noting how Columbus's voyage develops the term "cannibalism" in the discourse of European colonialism.

When Columbus discovered the land of the Americas in 1492, he reported that on one island, "there were men with one eye only, and others with faces like dogs, who were man-eaters, accustomed upon taking a prisoner to cut his throat, drink his blood and dismember him" (122-23). Since then, the discourse of cannibalism spreads all over the European world and became a "weapon used [by the white Europeans] to distinguish what they conceived of as their civilized selves from certain savage others, principally Native Americans and Africans" (Cheyfitz 42). More specifically, the notion that the white populace belongs to textuality, literacy and civilization while the black Other and Native American Other belong to orality, illiteracy and barbarity is constructed through the discourse of cannibalism. Moreover, the term "cannibalism" itself creates a kind of fear among both the white and the nonwhite, represented by the creation of the cannibal mother Sethe, the cannibal daughter Beloved and the cannibal Schoolteacher in Beloved.

\section{The Creation of the Cannibal Mother}

Howard and Buglar, Sethe's sons, ran away as soon as they became thirteen in order to avoid the "baby venom" (Beloved 17). For twelve years after Baby Suggs dies, no one visited 124. Not because they were afraid of the venomous ghost, but rather, the cannibal mother Sethe. When Paul D first visited 124, Denver complains that she can no longer bear to live in 124: "I can't live here. I don't know where to go or what to do, but I can't live here. Nobody speaks to us. Nobody comes by. Boys don't like me. Girls don't either" (Beloved 17). When Sethe tries to explain to Paul D that it is because a ghost has haunted the house, Denver stops her by exclaiming that "It's not! It's not the house. It's us! And it's you!" (Beloved 17), revealing that it is not the haunted house but her cannibal mother that horrifies the neighbors.

Denver's fear of her mother's cannibalistic impulse is derived from her mother's explanation of her runaway story when she was pregnant. According to Sethe, when she suspects that the voice that she hears at the Ohio River might be a "white boy" who has "mossy teeth, an appetite" she feels like "something [magical like moving jaws] came up out of 
the earth into her" (Beloved 38). Out of fear for the safety of her unborn child, Sethe becomes like a hungry "snake" with poisonous jaws (Beloved 38). Like a cannibal snake that is eager to survive, Sethe is ready to "bite into" the white boy's eyes and "gnaw[s] his cheek" (Beloved 38).

It is suggested that Sethe's cannibalistic transformation is derived from two aspects: the fear of white cannibalism and maternal love. Regarding the first aspect, historically, there were some incidents that occurred due to the fear of white cannibalism such as the Annibal revolt of 1729 and the mass suicide on Prince of Orange in 1737 (Rice 112). Quobna Ottobah Cugoano, a slave who had been caught by the Atlantic Slave Trade, wrote in his autobiography that "I saw several white people, which made me afraid they would eat me," which verifies the horrible fear of "white cannibalism" (Cugoano 134). As to the second aspect, mythologically, a snake symbolizes "fertility, rebirth and transformation," which signifies that Sethe's cannibalistic tendencyis a form of maternal transformation ("Myths Encyclopedia Serpents and Snakes", 2012). Moreover, Sethe associates her maternal cannibalistic impulse with God, claiming that if God were there "He would [...] eat his feet off" too (38). In Darrow L. Miller and Stan Guthrie's Nurturing the Nations: Reclaiming the Dignity of Women in Building Healthy Cultures, it is stated that

God's care is the archetype of the care of a nursing mother. The trait of being a nursing mother is derived from the primary nature of God's character in the imago Dei[image of God]. [...] a mother's love is compassionate and secure (womb), nurturing and comforting (breasts) and a protective covering (wings)... These female characteristics are a reflection of God's 'maternal' heart. (156)

Thus, if maternal care and maternal love are parallel to God's care and God's heart, is maternal cannibalism parallel to God's cannibalism? In the Bible, cannibalism is generally a warning about the horror that will fall upon those who do not obey God; it is regarded as a sin of apostasy in Christianity. Perhaps it is because of this reason that Sethe's murder case appears in a white newspaper that rarely reports on incidents involving black people:

there was no way in hell a black face could appear in a newspaper if the story was about something anybody wanted to hear...It would have to be something out of the ordinary-something whitepeople would find interesting, truly different, worth a few minutes of teeth sucking if not gasps. (Beloved 183)

Murdering one's own child sounds interesting but the-cannibal-child murderer can not only feed the white readers' interest but can also satisfy them by making them feel more civilized and thus superior. Furthermore, Sethe's murderous act has also awakened the fear of cannibalism among the nonwhite community. Ella, who had helped Sethe to run away from slavery, claims that she does not "know who Sethe is or none of her people" (Beloved 220) due to her fear of the cannibal Other:

"...how she have that baby in the woods by herself? Said a white woman come out the trees and helped her. You believe that? A white woman? Well, I know what kind of white that was."

"Aw, no Ella."

"Anything white floating around in the woods - if it ain't got a shotgun, it's something I don't want no part of!"

"You all was friends."

"Yeah, till she showed herself."

"Ella."

"I ain't got no friends take a handsaw to their own children." (Beloved 221)

Perhaps there are some missing parts in Ella's description above. Firstly, "Well, I know what kind of white that was...white cannibal"; Secondly, "Yeah, till she showed herself...as a cannibal". Ella's dissociation with Sethe is caused by the fear and disgust of white cannibalism that she felt during the time of slavery: "It was 'the lowest yet' who gave her a disgust for sex and against whom she measured all atrocities. A killing, a kidnap, a rape" (Beloved 301).

Unlike Ella who is afraid of the cannibal Sethe, Paul D repeatedly confirms to Stamp Paid that "This ain't [Sethe's] mouth. I know her mouth and this ain't it," which means that Sethe does not have a cannibal mouth (Beloved 183). What rather frightens him is what Sethe calls "a selfish pleasure":

It was a kind of selfishness I never knew nothing about before. It felt good. Good and right. I was big, Paul D, and deep and wide and when I stretched out my arms all my children could get in between. I was that wide. Look like I loved em more after I got here. Or maybe I couldn't love em proper in Kentucky because they wasn't mine to love. But when I got here, when I jumped down off that wagon-there wasn't anybody in the world I couldn't love if I wanted to. (Beloved, 190-191)

If Paul D. understood that a mother's love is a reenactment and a reflection of God's love, he would have understood Sethe's behavior. Like God's love, mother love itself is beyond the symbolic world, it is illogical, inexplicable and unjust in its way. Here, Sethe's claiming of her "selfishness" can be related to the power and ability that she has to control events. As a slave she had no control and no ability to do anything. But as a mother she has a responsibility to use her womb, her breasts, and her hands to secure, to nurture and to protect her children. Perhaps the way she shows her love is inhuman but that is the only way that she can show her love under the system of slavery. This brutality of slavery can be seen as a form of cannibalism as it forces a mother to kill her children in order to save her children from being dehumanized. From this perspective, Sethe's murderous act is beautiful in the sense that she wants to save her 
child from slavery and from injustice. Paradoxically, the dead child suffers another injustice, which is the deprivation of the right to live. This establishes another part of the story: the return of the cannibal daughter.

\section{The Return of the Cannibal Daughter}

When Beloved first appears in the story, neither cannibalistic nor "malevolent" but rather, seeming "exhausted" and "sick", she has "to rest her head in the palm of her hand as though it was too heavy for a neck alone" (Beloved 77, 60, 64, 67). It is through the feeding of "sweet things" (Beloved 66) by Denver and the storytelling of Sethe expressing her repressed memories in Sweet Home-earrings, wedding dress, honeymoon with Halle, her mother's mark and so forth - that Beloved becomes healthy. Similarly, Sethe is "licked, tasted, eaten by Beloved's eyes" (Beloved 66); it is the hunger of Beloved's "big black eyes" that urges Sethe to re-experience her traumas and thus she feels "an unexpected pleasure" when she overcomes those unspeakable pains (Beloved 68-69). This cannibalistic relationship between Sethe and Beloved is further emphasized in Chapter 22 of Beloved, in which Beloved can actually experience what Sethe sees, tastes, smells and touches in the Middle Passage because Sethe had chewed and swallowed her face:

The men without skin push them through with poles the woman is there with the face I want the face that is mine they fall into the sea which is the color of the bread she has nothing in her ears if I had the teeth of the man who died on my face I would bite the circle around her neck (Beloved 249)

Supposedly, the cannibalistic relationship between Sethe and Beloved is derived from the loss of maternal love, as some psychologists have linked cannibalism to "childhood trauma relating to separation anxiety from the mother and resulting oral aggression" (Business Insider 2). In "To be Loved and Cry Shame," Lynda Koolish states that "Sethe has a hallucination of Beloved's return because she associates the chance to be a mother with the longed for opportunity to be ma'am's child" (183). That is to say, Beloved's cannibalistic tendency is the projection of Sethe's craving for her mother love; the cannibalism that exists between them serves as a longing for connection - to be one with the mother.

Metaphorically, there is also a kind of cannibalism that exists between Denver and Beloved. Though, in Denver's case it is derived from the longing for a connection with the outside world. As Koolish has suggested, 'Beloved's return is the antidote to Denver's "original hunger," which is the period in her life in which she is isolated from the outside world after she is told about her mother's murderous act (Beloved 187). It is Beloved who feeds Denver's social hunger and Denver who feeds Beloved's psychical hunger. However, this relationship turns out to be cannibalistic when Denver realizes that after losing Beloved, she does not know "which part of her is an arm, a foot or a knee" because "she has no self"; she is "breakable, meltable and cold" (Beloved 144-145). This means that Beloved is Denver's yin just as Denver is Beloved's yang, that they are feeding on each other's energy in order to stay "alive" (145). This suggestion is supported by the idea that "cannibalism involves both the establishing of absolute difference, the opposites of consumer and consumed and the dissolution of that difference, through the act of incorporation which identifies them, and makes the two one" (Kilgour, 1990:7; Barker et al. Emphasis 240). Supposedly, this cannibalistic relation between Denver and Beloved is established through the blood/milk feeding, as "Denver took her mother's milk right along with the blood of her sister" (Beloved 179). In Collete, Julia Kristeva claims that taste is "a cannibalistic pleasure. Through taste I appropriate the other, assimilate it" (203). This signifies that the cannibalistic relationship between Beloved and Denver is established through tasting the blood/milk of Sethe.

The cannibalistic relationship between Sethe and Denver makes an end to the one between Denver and Beloved, as Denver, after seeing the terrible condition of her mother, decides to step out of 124 and ask for help. Without Denver's help, Sethe might die since she starves herself to satisfy Beloved in order to reduce her guiltfor murdering her while the daughter consumes her vitality until her belly looks like a "watermelon": "[Sethe] sat in the chair licking her lips like a chastised child while Beloved ate up her life, took it, swelled up with it, grew taller on it. And the older woman yielded it up without a murmur" (Beloved 295). After listening to Denver's description of Sethe's situation, Ella decides to gather the power of the female members in the community to exorcise the "grown up evil," Beloved (Beloved 302). Standing in front of 124, the women started to sing. Their voice was like "a wave of sound wide enough to sound deep water and knock the pods off chestnut trees" and it "broke over Sethe and she trembled like the baptized in its wash" (Beloved 308). Here, Linda Krumholz suggests that it is "the power of the women's voices" that "ritualizes Sethe's cycle from spiritual death to rebirth" (402). According to Krumholz, those voices are parallel to Baby Suggs's preaching in the Clearing, that they represent the spiritual power of a purgation ritual which "lies beyond the meaning of words, in sound and sensation rather than in logical meaning and the Logos" (403). Like Baby Sugg's "cleansing waters," those voices transfer Sethe back to the period of slavery in Sweet Home. However, surprisingly, this time, instead of murdering her own child, Sethe turns to attack the white man, Mr. Bodwin, who has been mistaken for Schoolteacher. Paradoxically, this act of Sethe actually kills Beloved as she "explodes" and "disappears" in the end (Beloved 310). As Koolish has suggested, "if Sethe reintegrates, and absorbs Beloved into her core self, Beloved will cease to exist as a separate entity," which means the swallowing and digestion of Beloved by Sethe ultimately makes Beloved disappear (190).

To sum up, Beloved represents the cannibal ghost who is fed by the unspeakable and unspoken memories and desires of every character that she meets in order to construct her own body and vitality. This condition of Beloved is parallel to the white slave-traders who are fed by the body, dignity and humanity of the black slaves in order to construct their own selves. In this sense, Beloved herself is a cannibal Other who literally serves as a projection of white cannibalism and at the same time is the victim of white cannibalism. On the other hand, Beloved functions as a catalyst for the whole nonwhite community who are traumatized and affected by slavery. In Cannibalism and The Colonial World, 
Ghosts are not horrifying apparitions from another, unwanted era but welcome catalysts for the recovery of a buried ancestral consciousness. Ghost stories, like ghosts themselves, shift the shape of the past(s) that they engage with; they are co-opted [...] into a discourse of conversion, whereby a history of exploitation is estranged even as it is confronted, and pattern is established for the transformation of individual trauma into the inspiring recollective force that bonds a whole community. (italic ours; Beloved 129-130)

Drawing on the statement above, it is suggested that the catalyst Beloved not only cures every character surrounding her by restoring their collective memory but also elevates memory to a higher form, which turns "a history of race-based conflict" into "a valuable source of artistic creativity" (Colonialism 130).

\section{The Cannibal Schoolteacher}

After acknowledging that Beloved herself is both the product of white cannibalism and the cure for it, this part focuses on the incidents that happened between Schoolteacher and Sethe, claiming that Schoolteacher's behavior is cannibalistic in the sense that he feeds upon Sethe's vitality, dignity and humanity in order to produce his own identity as a subject, while the cannibal mother, paradoxically, inflicting the barbarous act of love upon her child functions as a deconstruction of white cannibalism.

In what sense is Schoolteacher cannibalistic? Theoretically, his use of Setheas an experimental object to measure the supposed "human" and "animal" characteristics, depriving her of milk for her child, and marking her body, can only be seen as inhuman (Beloved 228). However, symbolically, those behaviors are connected to cannibalism. When Sethe is held by two of his men in order to take her milk, the whole time Schoolteacher is watching and taking notes. This gaze of Schoolteacher is metaphorically cannibalistic in that it dehumanizes Sethe from a woman/mother to a nonhuman. It is this gaze of Schoolteacher that compels the maternal defense system (offspring protection) of Sethe, turning her into a cannibal: "the nigger woman who looked like she didn't have any [eyes]. Since the whites in them had disappeared and since they were as black as her skin, she looked blind" (Beloved 177). The cannibal mother then cut her child's throat in order to save her own child from being fed to the white slave traders. Regarding this, according to Schoolteacher, it is in her nature, as a black, as an animal, to kill her child. It is only through the guidance of slavery that the blacks will not fall back into a primitive life (Rice 116); it is too much freedom that leads to barbarism:“" [...] a little so-called freedom imposed on people who needed every care and guidance in the world to keep them from the cannibal life they preferred" (Beloved 177). On the contrary, those who understand the horror of slavery see Sethe's murderous act as "self-mutilation," which "puts in crisis the boundaries between self and other and rends the master/slave hierarchy" (Heffernan 564). It represents the dismissal of "the Law of the Father/Master" and "exposes the implicit violence of the symbolic" (Heffernan 562). Harriet A. Jacob suggests that "it is through the capacity to feel 'mother agonies,' that the black woman may be elevated to the position of white mother" (70). What Sethe had experienced as a slave woman under the cruel dominance of Schoolteacher is nothing that a white woman can understand. Compared to the black mothers, the white mothers are able to develop the mother-child bonding because of their constant connection with their children. As for the black mothers, they do not even have the legal right to marriage, which prevents them from exercising the role of mother. Nevertheless, Sethe's "capacity to experience suffering raises her up from the position of the animal to occupy the "human condition" that is promoted by the whites (Goldman 316).

In addition to trying to save her child from becoming a slave, Sethe would also rather kill her child in order to save her from being written about by Schoolteacher in his notebook, which could "dirty you so bad you couldn't like yourself anymore. Dirty you so bad you forgot who you were and couldn't think it up" (Beloved 295). Ironically, it is Sethe who produces fine inks for Schoolteacher: "I made the ink, Paul D. He couldn't have done it if I hadn't made the ink" (Beloved 320). Thus, all merits and contributions of Schoolteacher are achieved through the blood and milk of Sethe (Goldman 325). In this sense, the notes taken by Schoolteacher serve as a tool to deconstruct his civilized characteristics since it precisely reflects his inhuman condition. In short, it is Schoolteacher's cannibalistic language and behavior that cannibalizes Sethe. Only by becoming a cannibal can Sethe deconstruct Schoolteacher's cannibalism, which leads to the reconstruction of her identity as a woman/mother/African-American.

Furthermore, the deconstruction of white cannibalism is set forth in Chapter 19, Beloved:

White people believed that whatever the manners, under every dark skin was a jungle. Swift unnavigable waters, swinging screaming baboons, sleeping snakes, red gums ready for the sweet white blood...But it wasn't the jungle blacks brought with them to this place from the other (livable) place. It was the jungle white folks planted in them. And it grew. It spread. In, through and after life, it spread, until it invaded the whites who had made it. Touched them every one. Changed and altered them. Made them bloody, silly, worse than even they wanted to be, so scared were they of the jungle they had made. The screaming baboon lived under their own skin; the red gums were their own. (Beloved 234)

Words associated with cannibalism, such as the screaming baboon, sleeping snakes, the red gums, blood and the jungle, are first planted by the whites on the blacks. However, slavery proves that those characteristics implanted on the black slaves actually belong to the white slave-traders. That is to say, it is the whites who deconstruct their own identity; they explode and end up being swallowed by their own cannibalism (slavery) in the end.

\section{Conclusion}

Cannibalism is a term utilized for constructing otherness but at the same time it dissolves otherness through assimilation. Throughout the fiction Morrison calls upon the reader to witness the embodiment of black selves- 
presented by Sethe, Denver, Beloved - through the deconstruction of white cannibalism, in which the society should no longer see the black body as "the dehumanized, materially dense object"; the black body should not be seen as edible object but rather a subject who holds freedom (Tompkins 213). Furthermore, Morrison presents the slavery itself as a form of cannibalism in Beloved implies that "those responsible for slavery are themselves cannibals" (Parker 634). Moreover, the presentation of Beloved as a cannibal encourages the reader to remember that the novel Beloved "is not a story to merely pass on" but to chew, swallow and digest inside oneself so that in the future there will be no sixty million and more people who get chewed and swallowed as has happened in the past (Beloved 323-324).

\section{References}

Barker, Francis, Hulme P. and Iversen M. (1998). Cannibalism and the Colonial World. Cambridge: Cambridge University Press.

Brown, L. (2012). "10 Things You Always Wondered About Cannibalism.” Business Insider. Accessed November 01, 2016. http://www.businessinsider.com/10-things-you-always-wondered-about-cannibalism-2012-5.

Cheyfitz, E. (1991). The Poetics of Imperialism: Translation and Colonization from the Tempest to Tarzan. New York: Oxford University Press

Columbus, Ch. (1994). Journal of the First Voyage to America 1492-1493. Health Anthology of American Literature Volume One, edited by Paul Lauter. Lexington: Health.

Cugoano, Q. O. (1995). Thoughts and Sentiments on the Evil and Wicked Traffic of Slavery...Black Atlantic Writings of the Eighteenth Century, edited by Adam Burr and Sarah Potkay. London: Macmillan.

Goldman, A. E. (1990). “'I Made the Ink': (Literary) Production and Reproduction in 'Dessa Rose' and 'Beloved' Feminist Studies 16 (2) : 313-30.

Heffernan, T. (1998). "Beloved and The Problem of Mourning." Studies in the Novel 30(4): 558-73.

Hichri, A. (2013). “Hunger 'Beyond Appetite': Nurture Dialectics in Toni Morrison’s Beloved.” Ariel 44(2): $195-220$.

Jacobs, H.A., Child L. M., and Yellin J F. (1987). Incidents in the Life of a Slave Girl: Written by Herself. Cambridge, MA: Harvard University Press.

Koolish, L. (2001). “'To Be Loved and Cry Shame’: A Psychological Reading of Toni Morrison's Beloved.”MELUS: Multi-Ethnic Literature of the United States 26, (4): 169-95.

Kristeva, J. (2005). Colettle (European Perspectives: A Series in Social Thought and Cultural Criticism. Translated by Jane Marie Todd. New York: Columbia University Press, .

Krumholz, L. (1992). “The Ghosts of Slavery: Historical Recovery in Toni Morrison's Beloved."African American Review 26(3): 395.

Miller, D. L. and Guthrie S. (2008). Nurturing the Nations: Reclaiming the Dignity of Women in Building Healthy Cultures. Colorado Springs: Paternoster, .

Morrison, T. (2004). Beloved. New York: Vintage

"Myths Encyclopedia." Serpents and Snakes. Accessed November 01, 2016. http://www.mythencyclopedia.com/SaSp/Serpents-and-Snakes.html.

Parker, E. (1998). "“Apple Pie' Ideology and the Politics of Appetite in the Novels of Toni Morrison.” Contemporary Literature 39 (4): 614-43.

Rice, A. (1998). “Who's Eating Whom': The Discourse of Cannibalism in the Literature." Research in African Literatures 29(4): 107-21.

Segan, E. (1976). Cannibalism. New York: Harper

Tompkins, K. W. (2007). “EVERYTHING'CEPT EAT US': The Antebellum Black Body Portrayed as Edible Body.” Callaloo. 30(1): 201-24. 